\title{
Correction to: Overrepresentation of Indigenous students in school suspension, exclusion, and enrolment cancellation in Queensland: is there a case for systemic inclusive school reform?
}

\author{
Linda J. Graham ${ }^{1}$ (D) $\cdot$ Callula Killingly ${ }^{1} \cdot$ Kristin R. Laurens $^{1,2} \cdot$ Naomi Sweller $^{3}$
}

(c) The Australian Association for Research in Education, Inc. 2022

\section{Correction to: The Australian Educational Researcher https://doi.org/10.1007/s13384-021-00504-1}

In the original publication of the article, the original citation "National Agreement on Closing the Gap (Australian Government, 2020)" was incorrectly cited as "(Australian Government, 2020)". And the authors' inclusion of an "Acknowledgement of Country" was missed.

The original article has been corrected.

Publisher's Note Springer Nature remains neutral with regard to jurisdictional claims in published maps and institutional affiliations.

The original article can be found online at https://doi.org/10.1007/s13384-021-00504-1.

Linda J. Graham

linda.graham@qut.edu.au

1 Centre for Inclusive Education, Queensland University of Technology (QUT), Brisbane, Australia

2 School of Psychology and Counselling, Queensland University of Technology (QUT), Brisbane, Australia

3 Department of Psychological Sciences, Macquarie University, Sydney, Australia 